\title{
PREDICTION OF BODY WEIGHT THROUGH BODY MEASUREMENTS IN BOERAWA (BOER x ETTAWA GRADE) BUCKS
}

\author{
S. Hadi ${ }^{1}$, P. Nugroho ${ }^{1}$, I. Harris ${ }^{1}$, K. Adhianto ${ }^{1}$ and W.P.B. Putra ${ }^{2 *}$
}

1- Department of Animal Science, Faculty of Agriculture, Lampung University, Soemantri Brodjonegoro No. 1 Rd, Rajabasa, Bandar Lampung 35145, Indonesia, 2- Department of Animal Production, Faculty of Animal Science, Gadjah Mada University, Fauna No. 3 Rd, Bulaksumur, Yogyakarta 55281, Indonesia, *Correspondence E-mail: banchet_putra18@yahoo.co.id

\section{SUMMARY}

This research was carried out to investigate the estimation of the body weight (BW) of Boerawa (Boer $x$ Ettawa grade) bucks by statistical methods.The bucks $(n=120)$ falling in two grades $(G 1$ and G2) were included in the resent investigation to estimate BW using body measurements. Average BW, heart girth (HG), body length $(B L)$ and withers height $(W H)$ of all goats were $38.00 \pm 3.78 \mathrm{~kg} ; 75.07 \pm 3.78 \mathrm{~cm} ; 65.02 \pm 2.47 \mathrm{~cm}$ and68.47 $\pm 3.92 \mathrm{~cm}$ respectively. Highest and positive correlation coefficient value between $B W$ and $H G$ were observed in $G 2$ bucks (0.69) and all goats (0.85). Independent sample T-test prosedure was adopted to eliminate unfit linear regression models in both grades. Model $A, D, E$ and $G\left(R^{2}>0.70\right)$ were found to be best accounting for prediction the $B W$ in $G 2$ buck.It was concluded that $H G$ is the best trait for the predicting $B W$ in $G 2$ buck. The most appropiate combination of body characteristics was observed between HG, BL and WH (model G with $\left.R^{2}=0.77\right)$ for the prediction of $B W$ in all animalsand $G 2$ buck.

Keywords: Boerawa buck, body weight, body measurements, regression, coefficient of determination

\section{INTRODUCTION}

The biometric measurements are use to assess several characteristic of animals. These measurements provide important evidences for the growth of the breed and the properties that change with environmental effects and feeding factors. In addition, body measurements are important data sources in terms of reflecting the breeds standards (Warwick et al., 1990) and are also important in giving information about the morphological structure and development ability of the animals. Body measurements differ according to factors such as breed, gender (sex), yield type and age. The most common parameters used for body measurements in goats are: head length, head depth, frontal with, ear length, body length, withers height, rump height, body depth, heart girth, width at withers, shank circumference, tail length and width. Body weight estimations are done using body measurements by different statistical analysis (Hifzan et al.,2015).

Body weight plays an important role in determining several characteristics of farm animals especially the ones having economical importance. Birth weight, early growth, feed convertion ratio as well as feeding requirements could be predicted by knowing the live weights of several stages of the kids (Tekle, 2014). Several charts that show the estimated weights according to body measurements are established in the countries where animal industry is developed. The variation of the body measurements is used as criteria in classification of the goats. The estimated values of the quantitative characteristics are useful in developing appropriate selection criteria (Blakely and Bade, 1998). The yields and the parameters that effect them are desired to be determined easily and inexpensive in animal breeding. If thedata regarding the yield properties are optained with difficult and expensive methods, then using indirect measurements could be an alternative way to be followed (Matsebula et al.,2013).

The relationship between body weight and economiccally important yields is well known in farm animals and body weight estimations using the body measurements is a matter of concern for sheep industry. In general the correlation between body measurement and body weight is found to be higher in sheep and goats. Therefore body weight can be predicted from morphometric measurements in pasture (Alex et al., 2010 and Ibrahim et al., 2014). Another important point is the enviromental effects, particulary from sustainability of the breed standards point of view crossing animals. The question of sustaining high yields and standards in different conditions is an essential concern for breeders. Therefore the results of studies regarding the breed standards of the crossing animals reared in their regions attract their attention.

Boerawa goat is one of the most popular meat type goat in Indonesia, especially in Gisting district, Tanggamus regency, Lampung province. Boerawa goat is one of crosbred goat in Indonesia which birth from Boer buck and Ettawa grade doe through artificial insemination (AI) technology. Since 2001 AI using Boer straw was done to Ettawa grade in Tanggamus regency. Some Boer goats (full blood) also imported from Australia for breeding programs in Malang regency. Boer goat is one of South African native goat, famous for meat production in the world because of their highly adult weight $(45-70 \mathrm{~kg}$ ) andaverage post-weaning daily gain about 245 to 250 g (Christopher, 2008). Sulastri et al. (2014) reported averages of yearling weight in Boerawa goat were $43.49 \mathrm{~kg}$ (grade 1) and $42.27 \mathrm{~kg}$ (grade 2).Averages 
forgestation length, litter size and birth weight of Boerawa doe (grade 1)were 159.31 days, 1.62 and $3.02 \mathrm{~kg}$ respectively (Adhianto et al.,2014). Dakhlan et al. (2011) reported averages for reproductive traits in second grade Boerawa doe such as birth weight $(2.94 \mathrm{~kg})$, first calving age (13.5 month), service per conception (2.00), conception rate $(>70 \%)$, kidding rate $(100 \%)$, kidding interval (11 month) and litter size (2.00).

The aim of this study was to examine the relationships between body measurements and body weight as well as investigate the prediction of live weight using some body measurements in Boerawa bucks reared in village breeding centre (VBC) conditions.

\section{MATERIALS and METHODS}

\section{Animals}

One hudred and twenty records were collected on Boerawa (Boer x Ettawa grade) bucks kept in village breeding centre (VBC) at Gisting district, Tanggamus regency, Lampung province, Indonesia. Two grades of Boerawa bucks (BG1 and BG2) were used in this study and each grade consisted of 60 goats with two pairs of permanent incisors ( $>2$ years age).

\section{Management of animals}

All animals were managed under a system that seems exactly like their original habitat under a semiintensive management system. On arrival the animal were given anti-stress to reduce fatigue and possible losses as a result of stress. Animals were let out to graze freely on the padlock during the day and $5.00 \mathrm{pm}$ where their feeding was supplemented with whole maize and dry grass forage consisting of drieddropped Panicum maximum, Gliricidia sepium and groundnut leaves and stalk as supplement feed to make up for their nutrient requirement. Fresh water was given ad-libitum. These lasted for twelve weeks after which the various measurements were taken.

\section{Animal measurements}

Body weight and body measuements of animals were recorded after eight hours of feed restriction. Linear body measurements were taken by a tape measure and body weight (BW) was taken using a digital scale. Heart girth (HG) was measured just behind the scapula by a tape measure. Body length (BL) was measure as the distance from the occipital joint to the first caudal vertebra. Withers height (WH) was measured as the distance from the surface of a platform to the withers.

\section{Statistical analysis}

The datawere edited using Microsoft Office Excel 2007 computer program. The complete randomized design (CRD) analysis was calculated through SPSS 16.0 software to test the effects of grade in linear models on BW, HG, BL and WH. When significant differences were observed between treatments, the means were compared using Duncanmultiple range test (DMRT). The model refering to Steel and Torrie (1995):
$Y_{i j}=\mu+G_{i}+E_{i j}$

where: $Y_{i j}$ is observations; $\mu$ is overall mean; $G_{i}$ is effect of the $i^{\text {th }}$ grade, $E_{i j}$ is experimental (residual) error.

Simple and multiple linear regression analysis were fitted to obtain prediction equations of $\mathrm{BW}$ from body measurements ( $\mathrm{HG}, \mathrm{BL}, \mathrm{WH})$ variables. Variable were resulted using enter regression method through SPSS 16.0 software and then used to develop the equations for BW. The model used for the linear regression analysis was as follows (Steel and Torrie, 1995):

$\mathrm{Y}=\mathrm{a}+$ bí $_{\mathrm{i}}+\mathrm{E}$

Where: $\mathrm{Y}$ is body weight (dependent variable), a is constanta or intercept, $b_{i}=$ regression coefficient of the $i^{\text {th }}$ independent variable, $X_{i}$ is the value of the $i^{\text {th }}$ independent variable and $E$ is the standard error of regression.

Accuracy of prediction equation for BW was estimated through the coefficients of determinations $\left(\mathrm{R}^{2}\right)$ and linear relationship between BW and other three body measurements using Pearson correlation coefficients (r) was also calculated. Best-fitted regression equation was developed to estimate $\mathrm{BW}$ through different linear regression equation models.

\section{RESULTS AND DISCUSSION}

\section{Body measurements}

Average body measurements and standard deviations of the two different grades are presented in Table 1. Research showed that the average of BW and BL in each grades were similar. The average of body weight ( $>1.5$ years age) in other Indonesian Boer cross (G2) goat was27.98 kg for Boercang (Boer x Kacang) as reported byDakhlan et al. (2011). Jiabi et al. (2000) and Villiers et al. (2009) reported that BW (>1 years age) of several Boer cross (F1) buckswere $49.95 \mathrm{~kg}$ (Boer x Renshou), $49.20 \mathrm{~kg}$ (Boer $x$ Jianyang Big-Ear), $55.33 \mathrm{~kg}$ (Boer $\mathrm{x}$ Chengdu Ma), 43.77 kg (Boer x Lezhi Black), 42.94 $\mathrm{kg}$ (Boer x Jialing),35.71 kg (Boer x Yingshan Black) and $27.60 \mathrm{~kg}$ (Boer $\mathrm{x}$ KwaZulu-Natal). The values obtained for BW (2PPI) in this study was generally lower than those obtained by Sulastri et al. (2014) inBG1 $(43.49+6.15 \mathrm{~kg})$ and BG2 $(42.27 \pm 2.12 \mathrm{~kg})$ bucks. However, the result obtained in this study as regards the differences of both gradesmeasurements were not similar to those reported by Sulastri et al. (2014) on Boerawa buck and caused by difference of doe (maternal) performance and management system.

\section{Correlation coefficients}

The correlation coefficient (r) indicating the relationship between the $\mathrm{BW}$ and linear body measurements are shown in Table 2. Highest $r$ valuewas showedbetween BL and $\mathrm{WH}$ in BG1 buck $(0.82)$. Therefore, negative $r$ value $(-0.21)$ seen between $\mathrm{HG}$ and BW in BG1 buck and included low category $(0.2<\mathrm{r}<0.40)$. Moderate rvalue $(0.40<\mathrm{r}<$ $0.70)$ were found between $\mathrm{HG}$ and $\mathrm{BW}$ in BG2 buck $(0.69)$ and high $r$ value $(0.70<r<0.90)$ were found in pooled (0.85). Correlation coefficient values 
between $\mathrm{HG}$ and BW (>2.0 years age) in several African native bucks such as Nigerian Red Sokoto (0.73), Red Sokoto (0.89), Afar (0.51), Abergelle (0.83), Hararghe Highland (0.89), West African Dwarf (0.93), Woyto-Guji (0.85), Mubende (0.79), Teso (0.75) and 0.59 for Lugware(Adeyinka and Ibrahim, 2006; Ibrahim et al., 2014; Tekle, 2014; Tadesse et al., 2012; Tsegaye et al., 2013; Fajemilehin and Salako, 2008; Lorato et al.,2015; Jimmy et al.,2010). High $\mathrm{r}$ value between HG and BW (0.83) also obtained by Baffour-Awuah et al. (2000) in two Ghana breeds of Djallonke and Sahelian. Meanwhile, moderate $r$ value $(0.64)$ betwen $\mathrm{HG}$ and BW was reported in Red Sokoto buck
(Egena et al., 2014). Therefore, r values between HG and $\mathrm{BW}(>1.5$ years age) in Asian native bucks of Beetal (0.71), Malabari (0.91)and 0.90 for Teddi (Khan et al., 2006; Alex et al.,2010; Moaeen-ud-Din et al.,2006). Pesmen and Yamdirci (2008) and Cam et al. (2010)reported that $\mathrm{r}$ values between $\mathrm{HG}$ and BW (>1.5 years age) in Saanen and Kilkeci goats (European breed) were 0.95 and 0.85 respectively. Adeyinka and Mohammed (2006) reported that the $r$ value between $\mathrm{HG}$ and $\mathrm{BW}$ in pooled buck (Red Sokoto and White Bomo) was 0.72. Research resulted that $\mathrm{HG}$ can be used topredict the $\mathrm{BW}$ through simple linear regression for most goat breeds.

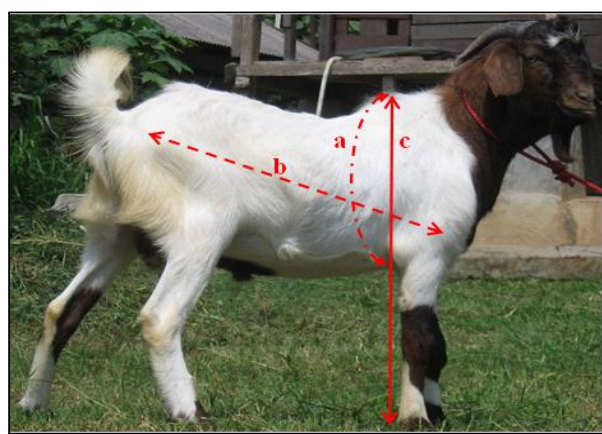

Figure 1. Body measurements of Boerawa (Boer $x$ Ettawa grade) buck. a) heart girth, b) body length, c) withers height

Table 1.Mean (

\begin{tabular}{|c|c|c|c|c|c|}
\hline Parameters & Mean & SD & CV (\%) & Min. & Max. \\
\hline \multicolumn{6}{|l|}{ Grade $1(\mathrm{~N}=60)$} \\
\hline Body weight (kg) & 34.85 & 1.72 & 4.94 & 31.50 & 38.40 \\
\hline Heart girth $(\mathrm{cm})$ & $71.99^{\mathrm{a}}$ & 0.67 & 0.93 & 71.00 & 73.50 \\
\hline Body length $(\mathrm{cm})$ & 63.90 & 2.40 & 3.75 & 61.00 & 71.00 \\
\hline Withers height $(\mathrm{cm})$ & $71.17^{\mathrm{a}}$ & 3.07 & 4.31 & 64.00 & 77.00 \\
\hline \multicolumn{6}{|l|}{ Grade $2(\mathrm{~N}=60)$} \\
\hline Body weight (kg) & 41.14 & 2.40 & 5.84 & 35.90 & 48.70 \\
\hline Heart girth $(\mathrm{cm})$ & $78.15^{\mathrm{b}}$ & 3.00 & 3.84 & 73.60 & 86.00 \\
\hline Body length (cm) & 66.14 & 2.00 & 3.02 & 62.50 & 71.00 \\
\hline Withers height $(\mathrm{cm})$ & $65.77^{\mathrm{b}}$ & 2.61 & 3.97 & 62.80 & 75.30 \\
\hline \multicolumn{6}{|l|}{ Overall $(\mathrm{N}=120)$} \\
\hline Body weight (kg) & 38.00 & 3.78 & 9.95 & 31.50 & 48.70 \\
\hline Heart girth $(\mathrm{cm})$ & 75.07 & 3.78 & 5.04 & 71.00 & 86.00 \\
\hline Body length $(\mathrm{cm})$ & 65.02 & 2.47 & 3.80 & 61.00 & 71.00 \\
\hline Withers height $(\mathrm{cm})$ & 68.47 & 3.92 & 5.73 & 62.80 & 77.00 \\
\hline
\end{tabular}

Means in the same column and parameter with different superscript differ significantly $(\mathrm{P}<0.05)$, N: number of observation, SD: standard deviation, CV: coefficient of variance, Min.: minimum value, Max.: maximum value.

Table 2. Correlation coefficient between body weight and body measuremets of Boerawa bucks

\begin{tabular}{lccc}
\hline \multicolumn{1}{c}{ Variables } & \multicolumn{3}{c}{ Body measurements } \\
\cline { 2 - 4 } & HG & BL & WH \\
\hline Grade 1 & -0.21 & 0.08 & -0.11 \\
Body weight (BW) & - & 0.06 & 0.18 \\
Heart girth (HG) & - & - & $0.82^{* *}$ \\
Body length (BL) & & & 0.19 \\
\hline Grade 2 & $0.69^{* *}$ & $0.38^{* *}$ & $0.28^{*}$ \\
Body weight (BW) & - & $0.41^{* *}$ & 0.12 \\
Heart girth (HG) & - & - & $-0.56^{* * *}$ \\
Body length (BL) & & & $-0.48^{* *}$
\end{tabular}


Body length (BL) 0.03

$*(\mathrm{P}<0.05), * *(\mathrm{P}<0.01)$

Table 3.Simple and multiple linear regression models for predicting body weight (a dependent variable) on body measurements (an independent variables) in Boerawa bucks

\begin{tabular}{|c|c|c|c|c|c|c|c|c|}
\hline \multirow[b]{2}{*}{ Equations } & \multirow{2}{*}{$\begin{array}{c}\text { Independent } \\
\text { variables }\end{array}$} & \multirow[b]{2}{*}{ Intercept } & \multicolumn{3}{|c|}{ Regression coefficient } & \multirow[b]{2}{*}{ MSE } & \multirow[b]{2}{*}{$\mathbf{R}^{2}$} & \multirow[b]{2}{*}{ Sig. } \\
\hline & & & HG & BL & WH & & & \\
\hline \multicolumn{9}{|l|}{ Grade 1} \\
\hline Model A & HG & 73.85 & -0.54 & - & - & 2.88 & 0.05 & 0.11 \\
\hline Model B & BL & 31.31 & - & 0.06 & - & 3.00 & 0.01 & 0.56 \\
\hline Model C & WH & 39.30 & - & - & -0.06 & 2.98 & 0.01 & 0.40 \\
\hline Model D & HG,BL & 70.72 & -0.56 & 0.07 & - & 2.91 & 0.05 & 0.21 \\
\hline Model E & $\mathrm{HG}, \mathrm{WH}$ & 74.41 & -0.51 & - & -0.04 & 2.92 & 0.05 & 0.23 \\
\hline Model F & BL,WH & 32.51 & - & 0.38 & -0.30 & 2.77 & 0.10 & 0.04 \\
\hline Model G & HG,BL,WH & 60.69 & -0.40 & 0.35 & -0.27 & 2.74 & 0.12 & 0.06 \\
\hline \multicolumn{9}{|l|}{ Grade 2} \\
\hline Model A & HG & -1.72 & 0.55 & - & - & 3.11 & 0.47 & 0.00 \\
\hline Model B & BL & 11.22 & - & 0.45 & - & 5.04 & 0.14 & 0.00 \\
\hline Model C & WH & 29.40 & - & - & 0.18 & 5.65 & 0.04 & 0.14 \\
\hline Model D & $\mathrm{HG}, \mathrm{BL}$ & -7.95 & 0.51 & 0.14 & - & 3.10 & 0.48 & 0.00 \\
\hline Model E & $\mathrm{HG}, \mathrm{WH}$ & -1.81 & 0.55 & - & 0.002 & 3.16 & 0.47 & 0.00 \\
\hline Model F & BL,WH & 3.40 & - & 0.43 & 0.14 & 4.99 & 0.16 & 0.01 \\
\hline Model G & HG,BL,WH & -8.02 & 0.51 & 0.14 & 0.002 & 3.15 & 0.48 & 0.00 \\
\hline \multicolumn{9}{|l|}{ Overall } \\
\hline Model A & HG & -25.64 & 0.85 & - & - & 4.07 & 0.72 & 0.00 \\
\hline Model B & BL & -11.12 & - & 0.76 & - & 10.92 & 0.24 & 0.00 \\
\hline Model C & WH & 74.72 & - & - & -0.54 & 9.97 & 0.31 & 0.00 \\
\hline Model D & $\mathrm{HG}, \mathrm{BL}$ & -30.80 & 0.81 & 0.13 & - & 4.03 & 0.72 & 0.00 \\
\hline Model E & $\mathrm{HG}, \mathrm{WH}$ & -5.86 & 0.76 & - & -0.19 & 3.69 & 0.75 & 0.00 \\
\hline Model F & $\mathrm{BL}, \mathrm{WH}$ & 25.00 & - & 0.78 & -0.55 & 6.30 & 0.57 & 0.00 \\
\hline Model G & HG,BL,WH & -10.38 & 0.63 & 0.27 & -0.25 & 3.42 & 0.77 & 0.00 \\
\hline
\end{tabular}

WH: withers height, BL: body length, HG: heart girth, MSE: mean square error of equation, $\mathrm{R}^{2}$ : coefficient of determination, Sig.: significance

Table 4. Difference between actual and predicted body weights using simple and multiple linear regression models $\left(\mathbf{R}^{2}>\mathbf{0 . 7 0}\right)$ in Boerawa bucks

\begin{tabular}{|c|c|c|c|c|c|c|}
\hline Items & Mean (kg) & SD & $\mathrm{CV}(\%)$ & Min. & Max. & Sig. \\
\hline \multicolumn{7}{|l|}{ Grade $1(N=60)$} \\
\hline Model A $\left(\mathrm{R}^{2}=0.72\right)$ & 35.55 & 0.57 & 1.61 & 34.71 & 36.84 & ** \\
\hline Model D $\left(\mathrm{R}^{2}=0.72\right)$ & 35.82 & 0.64 & 1.80 & 34.77 & 37.58 & $* *$ \\
\hline Model E $\left(\mathrm{R}^{2}=0.75\right)$ & 35.33 & 0.70 & 1.99 & 33.85 & 36.59 & $* *$ \\
\hline Model G $\left(\mathrm{R}^{2}=0.77\right)$ & 34.43 & 0.54 & 1.56 & 33.38 & 35.65 & $* *$ \\
\hline Actual & 34.85 & 1.72 & 4.94 & 31.50 & 38.40 & - \\
\hline \multicolumn{7}{|l|}{ Grade $2(N=60)$} \\
\hline Model A $\left(\mathrm{R}^{2}=0.72\right)$ & 40.79 & 2.55 & 6.26 & 36.92 & 47.46 & ns \\
\hline Model D $\left(\mathrm{R}^{2}=0.72\right)$ & 41.10 & 2.55 & 6.21 & 37.20 & 47.97 & ns \\
\hline Model E $\left(\mathrm{R}^{2}=0.75\right)$ & 41.04 & 2.20 & 5.35 & 38.01 & 46.43 & $\mathrm{~ns}$ \\
\hline Model $G\left(R^{2}=0.77\right)$ & 40.27 & 2.09 & 5.19 & 37.43 & 45.05 & ns \\
\hline Actual & 41.14 & 2.40 & 5.84 & 35.90 & 48.70 & - \\
\hline \multicolumn{7}{|l|}{ Overall $(\mathbf{N}=120)$} \\
\hline Model A $\left(\mathrm{R}^{2}=0.72\right)$ & 38.17 & 3.21 & 8.42 & 34.71 & 47.46 & * \\
\hline Model $\mathrm{D}\left(\mathrm{R}^{2}=0.72\right)$ & 38.46 & 3.24 & 8.42 & 34.77 & 47.97 & $*$ \\
\hline Model E $\left(\mathrm{R}^{2}=0.75\right)$ & 38.18 & 3.30 & 8.63 & 33.85 & 46.43 & ns \\
\hline Model G $\left(\mathrm{R}^{2}=0.77\right)$ & 37.35 & 3.30 & 8.84 & 33.38 & 45.05 & ns \\
\hline Actual & 38.00 & 3.78 & 9.95 & 31.50 & 48.70 & - \\
\hline
\end{tabular}

\section{Predictor equations}

A stepwise multiple regression analysis was carried out. Simple linear regression and partial regression equations for investigated breeds along with their reliability percentage and mean square error (MSE) are shown in Table (3). The coefficient of determination $\left(\mathrm{R}^{2}\right)$ indicates that body measurements success to describe variation in
BW.Thus HG accounted 5\% (BG1) and 47\% (BG2) of the variation in $\mathrm{BW}$, together with total variation $72 \%$.The $\mathrm{R}^{2}$ and MSE can be considered as an important criteria in selection of the appropriate linear model. The equations with larger $R^{2}\left(R^{2}<\right.$ 0.70)and smallest MSE showed arange similar to the range observed in actual weight category (Table 4). The result of the multiple regression analyses 
indicated that the addition of other measurements (BL and $\mathrm{WH})$ to $\mathrm{HG}$ would result in significant improvement in accuracy of prediction even though a small extra gain. This fact is clearly highlighted by the value of the $\mathrm{R}^{2}$ and by the other statistical parameters. The practical use of $\mathrm{HG}$ as a reliable, indirect way to estimate $\mathrm{BW}$ in selection work is encouraged by these results.

This results suggest that variables with high $\mathrm{R}^{2}$ and low MSE might be used to predict body weight. Low $\left(\mathrm{R}^{2}<0.40\right)$ and moderate $(0.40<$ $\left.\mathrm{R}^{2}<0.70\right) \mathrm{R}^{2}$ values of model A were found in BG1 (0.05) and BG2 (0.47) bucks. Low $\mathrm{R}^{2}$ value (Model A) also found in Beetal goat (0.15) and Afar (0.35) as reported by Moaeen-ud-Din et al. (2006) and Tekle (2014).The $\mathrm{R}^{2}$ values (Model $\mathrm{A}$ ) of several goat breeds such as Beetal (0.59), Kilkeci (0.71), Malabari (0.82), Mubende (0.90), Teso or Lugware (0.88), Black Bengal (0.94), Hararghe (0.79) and 0.78 for West African Dwarf (Iqbal et al., 2013; Cam et al., 2010; Alex et al. 2010; Jimmyet al. 2010; Rahman et al.,2008; Tsegaye et al., 2013 and Fajemilehin et al., 2008).Low and moderate of $\mathrm{R}^{2}$ values(Model $\mathrm{G}$ ) were found in BG1(0.12) and BG2 (0.48) bucks. The $\mathrm{R}^{2}$ values (Model $\mathrm{G}$ ) of several goat breeds such as Red Sokoto (0.56), Abergelle (0.71), Malabari (0.72) and 0.69 for Beetal (Adeyinka and Mohammed, 2006; Tadesse et al.,2012; Chitra et al., 2012 and Iqbal et al., 2013).

\section{CONCLUSION}

It is concluded that body weight of Boerawagrade 2 buck (BG2) can be estimated with a high accuracy using some body measurements. Using suitable statistical method can save us from extra expenses and time wasting. The highest $\mathrm{R}^{2}$ was obtained when all the body measurements were included in linear regression equation. This suggests that weight could be estimated more accurately by combiningtwo or more measurements than by girth only. Using measurements obtained readily and offering accurate prediction of body weight might be considered as a framework for a recording system in rural areas. In this way, the establishment and application of advanced statistical methods may become more practical. Moreover, economic value of crossbred goat allocated to special geographic region may be estimated better. Therefore, with such a management decision system, genetic and performance improvements may be more promising.

\section{ACKNOWLEDGEMENTS}

The authors would like to acknowledge Lampung governorship, Lampung province and the herd owners for theirs help and permission and their contribution in data collection. We would also like to thank Lampung provincial private administration for funding the project.

\section{REFERENCES}

Adeyinka, I.A. and D.M. Ibrahim, 2006. Accuracy of body weight prediction in Nigerian Red Sokoto Goats raised in North Eastern Nigeria using linear body measurements. Pak. J. Biol. Sci., 9(15): 2828-2830

Adeyinka I.A. and I. D.Mohammed, 2006. Relationship of liveweight and linear body measurement in two breeds of goat of Northern Nigeria. J. Anim. Vet. Adv., 5(11): 891-893

Adhianto, K., N. Ngadiono, Kustantinah and I.G.S. Budisatria, 2012. Long gestation, litter size, and birth weight Boerawa goat in rural areas in the district maintenance in Gisting district of Tanggamus regency. JPPT.,12(2):131-136

Alex, R., K.C. Raghavan and K.A. Mercey, 2010. Prediction of body weight of Malabari goats from body measurements under field conditions. J.Vet. Anim. Sci., 41:21-27

Baffour-Awuah, O., E. Ampofo and R. Dodoo. 2000. Predicting the liveweight of sheep by using linear body measurements. Ghana. Jnl. Agric. Sci., 33: 207-212

Blakely, J. and D.H. Bade, 1998. Animal Science, $4^{\text {th }}$ Ed. Gadjah Mada University Press. Yogyakarta, Indonesia.

Cam, M.A., M. Olfaz and E. Soydan, 2010. Possibilities of using morphometrics characteristic as a tool for body weight prediction in Turkish Hair goats (Kilkeci). Asian. J. Anim. Vet. Adv., 1-7

Chitra, R., S. Rajendran, D. Prasanna and A. Kirubakaran. 2012. Prediction of body weight using appropriate regression model in adult female Malabari goat. Vet. World., 5(7): 409-411

Christpher, D.L, 2008. Boer goat production: progress and perspective. Office of Vice Chancellor for Academic Affairs, University of Hawaii, Hilo, USA.

Dakhlan, A., H. Idalina and S. Sri, 2011. Production and reproduction performance of grade 2 of Boerawa goat with different feeds. Proceeding $4^{\text {th }}$ National Science and Technology Conference. University of Lampung, Indonesia. Pp. 211-227

Egena, S.S.A., D.N. Tsado, P. Kolo, P. Bonjo and M. Shehu-Adisa. 2014. Path coefficient analysis of body weight and body measurements in Red Sokoto goats (Caprahircus I) of Niger State, Nigeria. Revue Agriculture., 7: 4-11

Fajemilehin, O.K.S. and A.E. Salako, 2008. Body measurement chaacteristics of the West African Dwarf (WAD) goat in deciduous forest zone of Southwestern Nigeria. Afr. J. Biotechnol, 7(14):2521-2526.

Hifzan,R.M., I. Ismail and H. Yaakub, 2015. Growth pattern for body weight, height at withers, and body length of Kalahari red goats. Pak. J. Biol. Sci., 18(4): 200-203

Ibrahim, A.A., J. Aliyu, B. Babandi, U. Ibrahim and A.B. Amin, 2014. Relationship among body 
weight, testicular traits and linear body measurements of Red Sokoto bucks fed different levels of sabara (Guiera senegalensis) leaf meals. Iranian. J. Anim. Appl. Sci., 4(2): 335-340

Iqbal, M., K. Javed and N. Ahmad, 2013. Prediction of body weight through body measurements in Beetal goats. Pak. J. Sci., 65(4): 458-461

Jiabi, P., D. Zegao, C. Taiyong and G. Jiyun, 2000. Improvement effect of crossbreeding Boer goats and Sichuan native goats. http://www.goatcentral.com/crossbreeding.htm. Accessed August, 2014.

Jimmy, S., D. Muteteikka, R.D. Kugonza and D. Mpairwe, 2010. Variability in body morphometric measurements and their application in predicting live body weight of Mubende and Small East African goat breeds in Uganda. Middle-East. J. Sci. Res., 5(2):98-105

Khan, H., M. Fida, A. Riaz, N. Gul, Rahimullah and Z. Muhammad, 2006. Relationship of body weight with linear body measurements in goats. $\mathrm{J}$. Agric. Biol. Sci., 1(3):51-54

Lorato, Y., M.A. Kirman and B. Birhanu, 2015. Morphological characterization of indigenous Woyto-Guji goat type in Loma district, Southern Ethiopia. Afr. J. Agric. Res., 10(20):2141-2151

Moaeen-ud-Din, M.N., N. Ahmad, A. Iqbal and M. Abdullah, 2006. Evaluation of different formulas for weight estimation in Beetal, Teddi and crossbred (Beetal x Teddi) goats. J. Anim. Pl. Sci., 16(3):74-78

Matsebula, M., E. Bhebhe, J.F. Mupangwa and B.J. Dlamini, 2013. Prediction of live weight from linear body measurements of indigenous goats of Swaziland. Livest. Res. Rur. Dev., Vol. 25(8).

Pesmen, G. and M. Yardimci, 2008. Estimating the live weight using some body measurements in Saanen goats. Archiva Zootechnica., 11(4): 30-40
Rahman, A.H.M.S., M.A.M.Y. Khandoker, S.S. Husain, S.S. Apu, A. Mondal and D.R. Notter, 2008. Morphometric characterization and relationship of body weight with linear body measurements in Black Bengal buck. Bang. J. Anim. Sci., 37(2): 8-16

Steel, R.G.D. and J.H. Torrie, 1995. Principle and procedure of statistics: a biometrical approach, $4^{\text {th }}$ Ed. Mc-Grawhill International Book Inc. Toronto, Canada.

Sulastri, Sumadi, T. Hartatik. and N. Ngadiono, 2014. Growth performance of Boerawa goat at Village Breeding Centre, Dadapan village, Sumberejo subdistrict, Tanggamus regency, Lampung province. Sains Peternakan., 12(1): 1-9

Tadesse, A., T. Gebremariam and S.K. Gangwar, 2012. Application of linear body measurements for predicting body weight of Abergelle goat breed in Tigray Region, Northern Ethiopia. GJJB., 1(2): 314-319

Tekle, T., 2014. Predicting live weight using body measurements in Afar goats in north eastern Ethiopia. MEJS., 6(2):18-32

Tsegaye, D., B. Berhanu and H. Aynalem, 2013. Linear body measurements as predictor of body weight in Hararghe Highland goats under farmers environment: Ethiopia. Global Veterinaria., 11(5):649-656

Villiers, J.F., S.T. Gcumisa, S.A. Gumede, S.P. Thusi, T.J. Dugmore, M. Cole, J.F. Toit, A.F. Vatta and C.F. Stevens, 2009. Estimation of live body weight from the heart girth measurement in KwaZulu-Natal goats. Appl. Anim. Husb. Rur. Dev., 1:1-8

Warwick, E.J., J.M. Astuti and W. Hardjosubroto, 1990. Animal breeding. Gadjah Mada University Press. Yogyakarta, Indonesia. 